\title{
A New Sweep Up /Down Phenomenon between the Chaotic and Regular Regions in a New R2L2D Circuit*
}

*The short version of that study was presented in ICEMIS 2015-International Conference on Engineering \& MIS.

\author{
Erol KURT ${ }^{1}$, Cihan BINGG̈̈L ${ }^{2}$ \\ ${ }^{1}$ Gazi University, Technology Faculty, Electrical and Electronics Engineering Department \\ ${ }^{2}$ Gazi university, Institute of Sciences, Electrical and Electronics Engineering Department
}

(Geliş / Received : 18.11.2015 ; Kabul / Accepted : 15.12.2015)

\begin{abstract}
R2L2D circuit becomes a chaotic circuit at certain frequencies and amplitudes. In the present study, new and strange phenomena, which is encountered in a newly-developed circuit, namely R2L2D circuit is reported. This new phenomena, which we called as the "sweep up/down effect" has been observed when the successive dynamic responses of the circuit have been explored by only adjusting the peak-to-peak amplitudes Vpp at a constant feeding frequency, namely $f=65 \mathrm{kHz}$. In one of our recent paper [13], this new circuit has been explored for a wide feeding amplitude and frequency regimes, whereas this effect has not been recognized at that time due to the lack of sensitivity. However, the detailed observations prove that the sweep up/down effect governs the identification of the dynamics in terms of periodic and chaotic regimes. Thus it gives a kind of uncertainty region at the threshold of the regimes depending on the feeding voltage increase or decrease. Besides, for a certain system parameter, i.e. $V p p$, the chaotic and periodic region co-exists phenomenologically. This effect becomes vital for the synchronization and encryption studies in the sense that the decrease/increase in amplitude certainly yield to regular or chaotic behavior in the output. In addition, the transitions from regular regime to the chaotic one or vice-verse takes place without any period doubling procedure apart from the traditional observations.
\end{abstract}

Keywords: sweep up, sweep down, regular, chaotic, RLD circuit

\section{Yeni R2L2D Devresinde Kaotik ve Düzenli Bölgeler Arasında Yeni Bir Yukarı/Aşağı Geçiş Olgusu*}

\author{
*Bu çalışmanın klsa formu ICEMIS 2015- International Conference on Engineering \& MIS \\ konferansinda sunulmuştur.
}

$\ddot{O Z Z}$

R2L2D devresi belirli frekans ve genliklerde kaotik devreye dönüşür. Bu çalışmada, yeni geliştirilen bir devrede yani R2L2D devresinde karşılaşılan yeni ve ilginç bir olguyu sunmaktayız. "Frekans yukarı/aşağı geçiş etkisi” olarak adlandırdığımız bu olgu, sabit besleme frekansında yani $f=65 \mathrm{kHz}$ de sadece tepe-tepe gerilimleri $V p p$ ayarlanarak devrenin peşpeşe dinamik tepkileri araştırıldığında gözlemlenmiştir. Son çalışmalarımızdan birinde [13], bu yeni devre geniş bir besleme gerilimi ve frekans rejimleri için araştırılmış; ancak bu olgu, hassasiyet eksikliğinden dolayı o zaman gözlemlenememişti. Ancak, ayrıntılı gözlemler göstermektedir ki; frekans yukarı/aşağı geçiş etkisi, periyodik ve kaotik rejimler açısından dinamiğin belirlenmesinde büyük rol oynamaktadır. $\mathrm{Bu}$ nedenle, besleme geriliminin artış ya da azalışına bağlı olarak rejimlerin eşiğinde bir tür belirsizlik bölgesi bulunduğu doğrulanmıştır. Ayrıca belli bir sistem parametresi yani Vpp için kaotik ve periyodik bölgelerin, fenomenolojik olarak bir arada bulunduğu anlaşılmıştır. Bu etki, genlikte artış azalışın hiç şüphesiz çıkş̧ta düzenli ya da kaotik davranışı sağlaması bağlamında senkronizasyon ve şifreleme çalışmaları için hayati olmaktadır. İlaveten; düzenli rejimden kaotik rejime ya da tersine geçişler geleneksel gözlemler dışında herhangi bir periyot katlama olmaksızın meydana gelmektedir.

Anahtar Kelimeler: yukarı geçiş, aşağı geçiş, düzenli, kaotik, RLD devresi

\section{INTRODUCTION (GİİŞ)}

Nonlinear electrical circuits are of great interest due to their wide application areas in engineering and natural sciences [1-8]. $\quad$ A great research, both theoretical and experimental has been performed on nonlinear

\footnotetext{
* Sorumlu Yazar (Corresponding Author)

e-posta: ekurt@gazi.edu.tr

Digital Object Identifier (DOI) : 10.2339/2016.19.3 305-310
}

electronic circuits because the nonlinear circuits provide a convenient framework for undertaking a systematic exploration of mechanisms underlying the onset of chaos [9]. While the researchers mainly focus on the encryption, signal masking and synchronization studies, another motivation comes from the understanding of chaos phenomena in this manner [512]. Following the invention of chaos in the basic electrical circuit RLD by Linsay [12], the generation of 
the chaotic behavior in those circuits have been a popular research topic $[13,14,15]$. Historically, the first observations of Linsay [12] and Testa [14] on the RLD circuit proved that a certain periodic steady state behavior with the same period as the voltage source occurs as long as the source amplitude $V$ is sufficiently small. However, if a certain feeding amplitude $V$ is adjusted to the input, the actual period of the steady state periodic output doubles. Thus for $V$ values, just above the critical voltage, the output voltage over the resistor indicates a $1 / 2$ subharmonic, so called "bifurcation". When $V$ is increased further, an entire sequence of period-doubling bifurcations have been observed such as 1/4, 1/8, 1/16 subharmonics. At the end of certain bifurcations, the previous steady state cannot be observed anymore. In fact, the output signals are chaotic except for some small transient periodic regimes. The odd subharmonics have also been observed for increasing $V$ in this circuit $[12,14]$. Azzouz et al carried out a theoretical exploration on the same circuit for the identification of the subharmonic features [16]. They modeled the diode as a varactor diode and observed even and odd subharmonics. They also emphasized the effect of nonlinear diode capacitance rather than the effect of sharp delay [16]. There exist a number of different studies realized with this circuitry in order to shed a light on the route to chaos in terms of the successive bifurcations, which take place just before the chaotic regime [17-20]. In addition, the ordinary RLD circuit has been considered a good circuitry for the determination of so-called "Feigenbaum parameters", which explains a universal recurrence relation of the trajectories in the bifurcation map [14-18]. It was proved that the bifurcation map obtained from the RLD circuit exhibits an ideal cycle with the Feigenbaum parameter $=4.669$.

The RLD circuit has been used for both the determination of bifurcation and the quasi-periodicity [18-20]. From the point of time series analysis, some remarkable studies on the output voltages of the RLD circuit have been carried out. For instance, one author of this paper used a statistical test to evaluate the nonlinear responses of the RLD circuit by introducing an embedding dimension [21-22].Thereby a classification of the output signals was realized in a statistical manner.

Although different orientations of RLD circuits have been studied in the recent years $[13,23,24]$, there is not any report on the sweep up/down effect, where the voltage increase/decrease direction (i.e. sweep up/down) affects the dynamic regime. Besides, a sudden transition occurs between the chaotic and periodic regimes in the present circuitry.

In one of our recent paper [13], the dynamic behavior of the forward and reversed biased diode systems (i.e. R2L2D circuit) have been discussed for a wide parametric region (i.e. on the $V-f$ plane) with less sensitive internal. In the same study, a bifurcation analysis based on the manifold theory has also been presented in order to determine the bifurcation characteristics on the route to chaos in R2L2D circuit.

In the same paper, the importance of the input signal frequency $f$ and the resistor $R$ is also emphasized for the bifurcation map of the system and a wider chaotic region has been observed in the new circuitry compared to the traditional $R L D$ circuit starting from $f=40 \mathrm{kHz}$, when the appropriate $V$ is adjusted from the input. However the phenomenon reported in the present paper has not been recognized in previous study due to the lack of sufficient sensitivity.

The paper is organized as follows: Section 2 briefly describes the proposed circuit and presents the experimental details for the observation of the observed phenomenon. The main experimental results are discussed in Section 3. Finally the paper ends with a brief conclusion on the main findings.

\section{R2L2D CIRCUIT (R2L2D DEVRESI)}

\subsection{Theoretical Background (Teorik Arkaplan)}

The proposed R-2L-2D circuit is shown in Fig. 1. The voltage equality of the circuit can be stated as follows: $V_{R}+V_{L D}=V$

where $V_{L D}$ denotes the voltage over the inductor and diode. As seen in Fig. 1., the diodes are inversely attached to the inductors in each branch. While current $I$ from the main branch is divided into $I_{1}$ and $I_{2}$ on each branch, the negative and positive alternates of the sinusoidal voltage pass through the branches over the entire period.

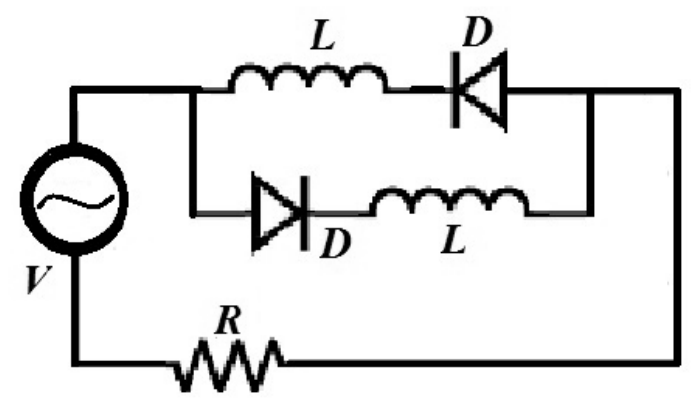

Figure 1. The R2L2D circuit with input voltage $V=V_{0} \sin$ $(\omega t) \quad\left(V=V_{0} \sin (\omega t)\right.$ giriş gerilimi ile $R 2 L 2 D$ Devresi)

Therefore,

$V_{L D}=V_{D 1}+L \frac{d I_{1}}{d t}$

(2)

$V_{L D}=V_{D 2}-L \frac{d I_{2}}{d t}$

can be written. Considering Fig.1 and the equations above, one arrives at

$\frac{d I_{1}}{d t}=\frac{V_{D 1}}{L}+\frac{V}{L} \sin (\omega t)-\frac{R}{L}\left(I_{1}+I_{2}\right)$

$\frac{d I_{2}}{d t}=\frac{V_{D 2}}{L}+\frac{V}{L} \sin (\omega t)-\frac{R}{L}\left(I_{1}+I_{2}\right)$ 
Here $I_{1}$ and $I_{2}$ denote the branch currents and $I=I_{1}+I_{2}$ is valid. Note that $V_{D 1}$ and $V_{D 2}$ are used for the voltages over the diodes. Strictly speaking they can be written as,

$V_{D 1}=\frac{k T}{e} \ln \left(\frac{I_{1}}{I_{S}}+1\right)$

$V_{D 2}=\frac{k T}{e} \ln \left(\frac{I_{2}}{I_{S}}+1\right)$

so that the nonlinear behavior of the diodes is important for the dynamics of the circuits [13]. Here a saturation current term $I_{S}$ is also included as a characteristic feature of the diode (i.e. $I_{S}=2.55 n A$ for $1 \mathrm{~N} 4007$ diode). The dimensionless form of the equation system can be written as,

$\frac{d I_{1}}{d t^{\prime}}=\frac{k T}{e L} \operatorname{In}\left(\frac{I_{1}}{I_{S}}+1\right)+\frac{V}{L} \sin \left(\Omega t^{\prime}\right)-\frac{R}{L}\left(I_{1}+I_{2}\right)$

$\frac{d I_{2}}{d t^{\prime}}=\frac{k T}{e L} \operatorname{In}\left(\frac{I_{2}}{I_{S}}+1\right)+\frac{V}{L} \sin \left(\Omega t^{\prime}\right)-\frac{R}{L}\left(I_{1}+I_{2}\right)$

Here time scaling $t^{\prime}=\tau \mathrm{t}$ can be considered and $\tau$ is determined by the circuit elements characteristics such as $\tau=L / R$. Here, $\tau$ represents the natural period of the circuit and it cannot be related to the period of applied voltage $V$. In addition $\Omega=\omega / \tau=\omega R / L$.

\subsection{Experimental Background (Deneysel Arkaplan)}

The experimental setup has been constructed according to Fig. 1. The resistance and the inductor values are $R=1 \mathrm{k} \Omega$ and $L=10 \mathrm{mH}$, respectively. $1 \mathrm{~N} 4007$ diodes are used in the experiments. The circuit has been driven by a GW Instek AFG-2125 function generator by supplying a sinusoidal feeding with an adjustable frequency $f$ and an amplitude $V$. For the circuit measurements and phase space observations, a Kenwood DCS-7020 oscilloscope has been used.

In the proposed circuit, the diodes become parallel to each other. Thus, while the current passes through one of the diodes in one direction, the other one does not allow the current. The current always flows through one of the diodes for any $f$ values. This situation causes a finite voltage on $R$ for the entire period of the circuit with the influence of voltage $V_{L D}$. Besides, the period doubling can also be observed while different $V$ and $f$ values have been applied to the circuit input.

During the parameter scan, a number of period doubling behaviors have been observed as in the ordinary $R L D$ circuit. For this specific observation, the voltage increment step is adjusted to $\Delta V=0.001 \mathrm{~V}$ and the frequency has been kept constant to some values such as $f=60 \mathrm{kHz}, f=65 \mathrm{kHz}$ and $f=80 \mathrm{kHz}$ to give better sensitivity on the input voltage exploration in the present paper. However the behavior for entire $V-f$ plane can be obtained from Ref. [13] for lower resolution.

\section{RESULTS AND DISCUSSION (SONUÇLAR VE TARTIŞMA)}

Initially, the chaotic signals can be obtained at a specific frequency and voltage. For instance, a signal with chaotic regime has been obtained as shown in Fig. 2 . The signal always changes in frequency and amplitude, when time passes. When another input amplitude / frequency is applied, the chaotic signal changes in amplitude. In addition, it yields to a broad frequency spectra at the vicinity of main frequency as seen in several traces in the waveform (Fig. 3).

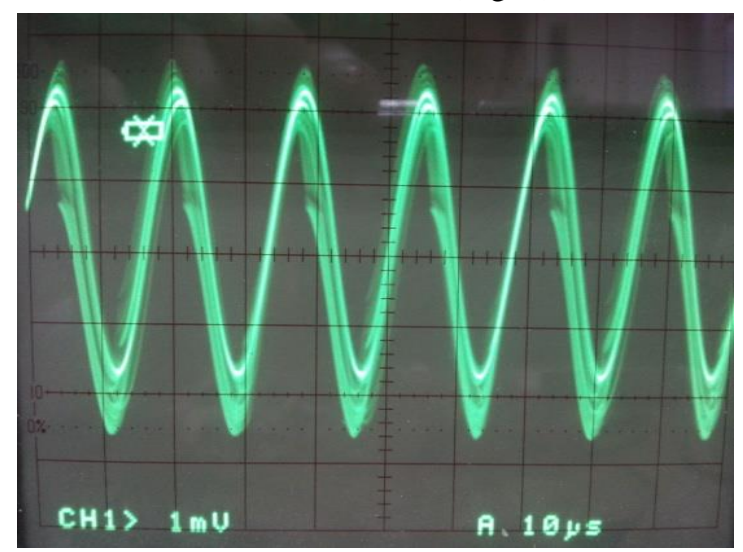

Figure 2. A chaotic signal formed attractor from the R2L2D circuit. The input parameters are $V_{p p}=8.36 \mathrm{~V}$ and $f$ $=58.4 \mathrm{kHz} .(\mathrm{R} 2 \mathrm{~L} 2 \mathrm{D}$ devresinden elde edilen kaotik sinyal. Giriş parametreleri, $V_{p p}=8.36 \mathrm{~V}$ ve $f=58.4$ kHz.)

Three representative attractors from the periodic, quasiperiodic and chaotic regimes are presented in Figs. 4-6. Fig. 4 shows the characteristic periodic attractor having a "sweet package" form. Note that $x$ and $y$ axes are the input voltage $V$ and voltage over $R, V_{R}$, respectively. This periodic form shows a period two $(2 \mathrm{P})$ regime with two trajectories.

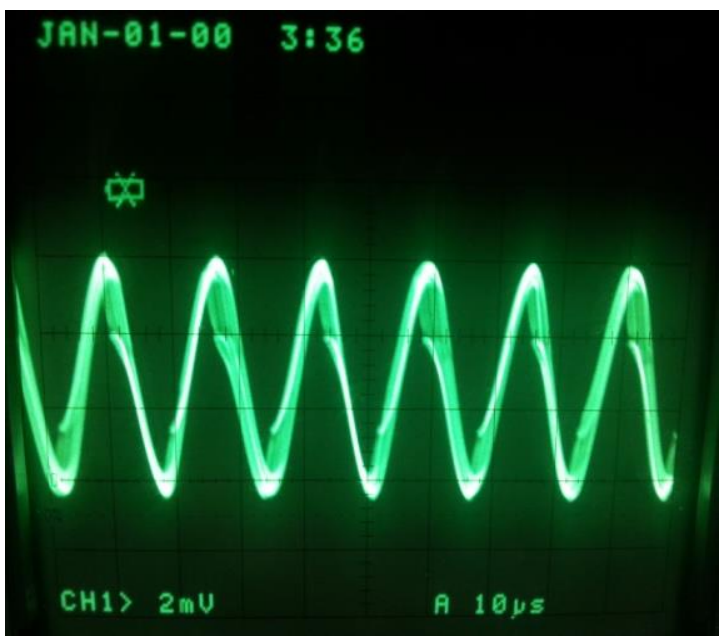

Fig. 3. A chaotic signal formed attractor from the R2L2D circuit. The input parameters are $\mathrm{V}_{\mathrm{pp}}=4.010 \mathrm{~V}$ and $f=62 \mathrm{kHz}$. (R2L2D devresinden elde edilen kaotik sinyal. Giriş parametreleri, $V_{p p}=4.010 \mathrm{~V}$ ve $f=62$ kHz.) 
When $V$ is increased up to $V p p=6.47$ at the same frequency, the attractor in Fig. 5 is obtained. This attractor mainly gives a quasi-periodic regime, which appears just before the chaotic one. The trajectories change from the attractor in Fig. 4, substantially.

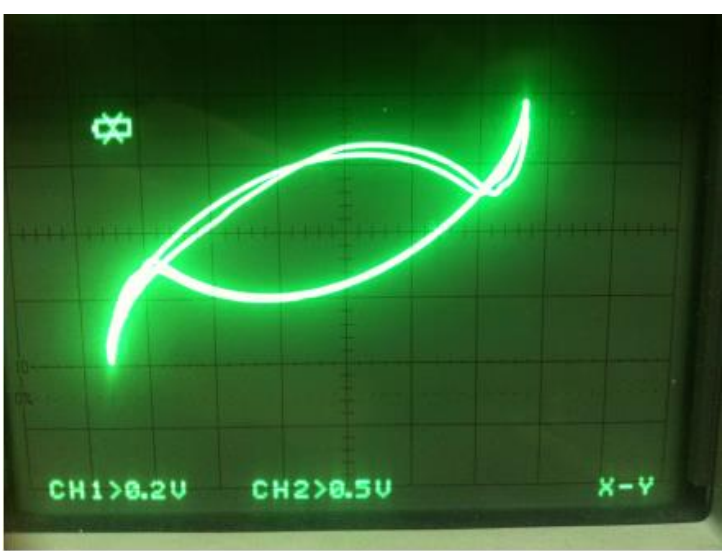

Figure 4.A representative "sweet package" formed attractor from the R2L2D circuit. The input parameters are $V p p=1.49 \mathrm{~V}$ and $f=60 \mathrm{kHz} . x$ and $y$ axes are the input voltage $V$ and voltage over $R, V_{R}$, respectively. (R2L2D devresinden elde edilen örnek bir "şeker paketi" biçimli çekici. Giriş parametreleri $V p p=$ $1.49 \mathrm{~V}$ ve $f=60 \mathrm{kHz}$. $x$ ve $y$ eksenleri sırasıyla giriş gerilimi $V$ ve $R$ üzerinde gerilim $V_{R}$ 'dir. )

however still some trajectories can be seen clearly as the indicator of the quasi-periodic regime.

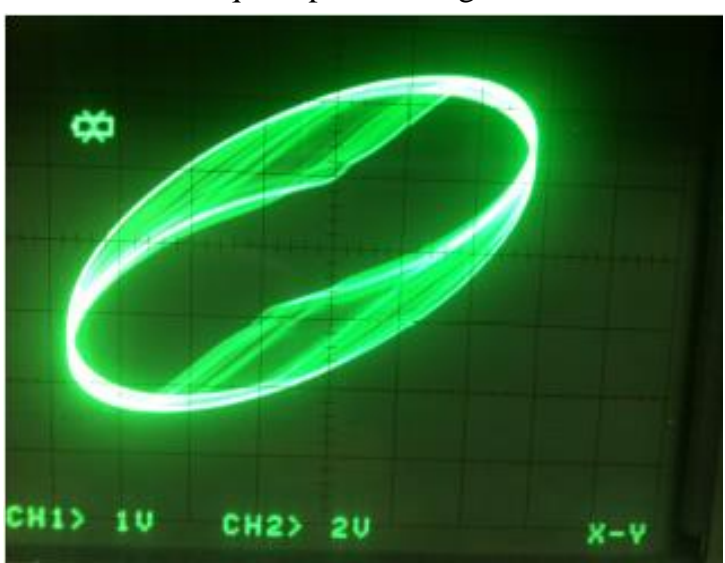

Figure 5. A representative quasi-periodic

attractor from the R2L2D circuit. The input parameters are $V p p=6.47 \mathrm{~V}$ and $f=60 \mathrm{kHz} . x$ and $y$ axes are the input voltage $V$ and voltage over $R, V_{R}$, respectively. (R2L2D devresinden elde edilen örnek bir sözdeperiyodik çekici. Giriş parametreleri $V p p=6.47 \mathrm{~V}$ ve $f=60 \mathrm{kHz} . x$ ve $y$ eksenleri sırasıyla giriş gerilimi $V$ ve $R$ üzerinde gerilim $V_{R}$ 'dir.)

A sample chaotic attractor can be shown in Fig. 6. This chaotic regime can be obtained for a moderate voltage and higher $f$ values. Note especially the intense points inside the trajectories, which represent the chaotic output.
When the amplitude and frequency of the input signal are increased, another chaotic attractor is obtained as in Fig. 7. Note that that attractor has much complicated trajectories on the phase plane with higher chaoticity.

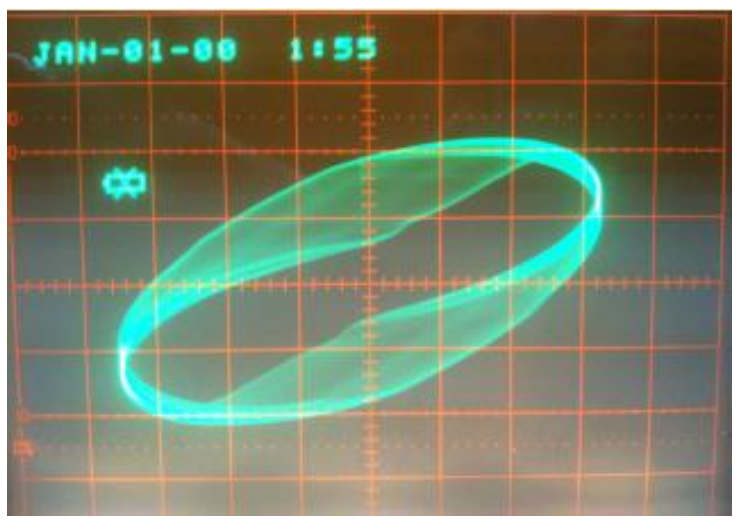

Figure 6. A chaotic attractor from the R2L2D circuit. The input parameters are $V p p=3.379 \mathrm{~V}$ and $f=80 \mathrm{kHz} . x$ and $y$ axes are the input voltage $V$ and voltage over $R, V_{R}$, respectively. (R2L2D devresinden elde edilen kaotik bir çekici. Giriş parametreleri $V p p=3.379 \mathrm{~V}$ ve $f=80 \mathrm{kHz}$. $x$ ve $y$ eksenleri sirasıyla giriș gerilimi $V$ ve $R$ üzerinde gerilim $V_{R}$ 'dir.)

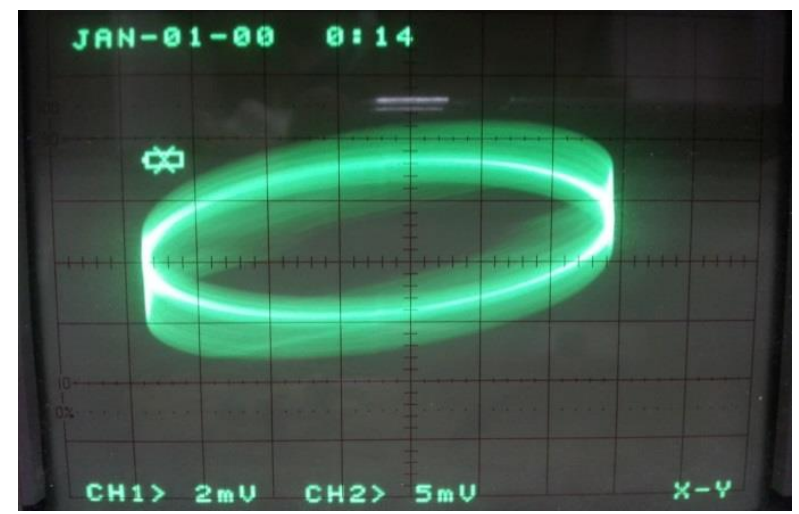

Figure 7. A chaotic attractor from the R2L2D circuit. The input parameters are $V_{p p}=8.16 \mathrm{~V}$ and $f=153.3 \mathrm{kHz}$. (R2L2D devresinden elde edilen kaotik bir çekici. Giriş parametreleri $V_{p p}=8.16 \mathrm{~V}$ ve $f=153.3 \mathrm{kHz}$.)

After a survey among different dynamical regimes, the sweep up/down phenomenon, which is encountered in this basic circuit can be clarified in detail. Fig. 8 shows the sweep up/down effect with both the directions of voltage increase/decrease and the responses of the system.

The diagram shows various attractors at the left and right hand side of the diagram. The left column corresponds to the case where the input voltage $V$ has been gradually increased by high sensitivity via $\Delta V=1$ $m V$ (i.e. sweep up). On the other hand, the right column corresponds to the case where $V$ has been decreased (i.e. sweep down) in the same manner. 
If $V$ is increased from the value such as $V=6.500 \mathrm{~V}$, the dynamics goes to the chaotic regime as indicated at the lower attractor of the left panel. According to the detailed analyzes, this chaotic regime survives until we arrive at $V=7.179$. After very small interval, this regime suddenly changes to a regular one as shown in the attractor located at the top of the left panel. As one recognizes clearly from the attractor, chaos is certainly obtained for $V=6.963 V$. When $V$ is increased to $V=$ 7.180 , a sudden periodic attractor with $2 \mathrm{P}$ appears.

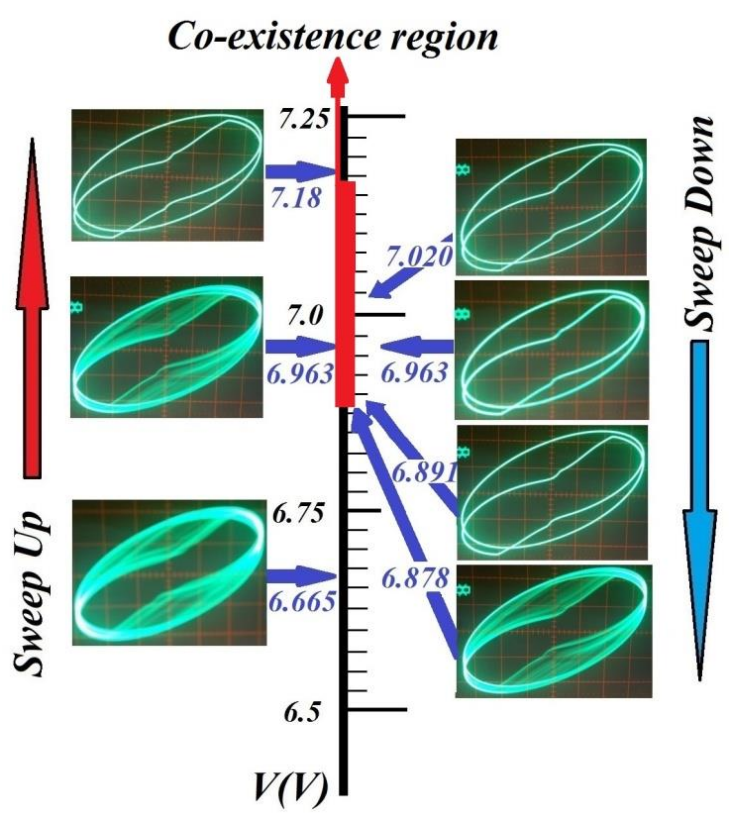

Figure 8. The sweep up/down diagram from the R2L2D circuit. The input frequency $f=65 \mathrm{kHz} . x$ and $y$ axes are the input voltage $V$ and voltage over $R, V_{R}$ , respectively. (R2L2D devresinden elde edilen yukarı/aşağı geçiş diyagramı. Giriş frekansı $f=65$ $k H z . x$ ve $y$ eksenleri sırasıyla giriş gerilimi $V$ ve $R$ üzerinde gerilim $V_{R}$ 'dir. )

Since we arrive at $V=7.250 \mathrm{~V}$, the sweep down case can be adjusted to the circuit just by adjusting lower input voltages. When the voltage is gradually decreased, the periodic attractor still persists till $V=6.891 \mathrm{~V}$ as seen in the third attractor from the top at the right panel. Note that the types of the attractors are same for $V=7.020 \mathrm{~V}$, $V=6.963 V$ and $V=6.891 V$ according to the attractors at the top of the right panel and the second one from the top of the right panel. In fact, period 2 (2P) regime continues till $V=6.877 \mathrm{~V}$. The chaotic regime appears suddenly at $V=6.878 \mathrm{~V}$.

Considering both sweep up and down cases, the chaotic region comes later from the value which is observed at the sweep up case. In addition, the periodic region appears for lower values (i.e. till $V=6.891 V$ ) at sweep down case compared to the sweep up case, which is observed at $V=7.180$. Thus, one can not directly say that the regime for a certain region of input voltages (for instance, $V=6.963 V$ ) is chaotic or periodic. Therefore it is a co-existence point which disables one to identify the real regime. Thereby, the direction of the voltage adjustment plays a significant role to identify the dynamic regime in the system.

Another interesting point is that the circuit indicates a sudden transition between the chaotic and periodic regimes. We believe that this sweep up/down effect and the sudden transition in this circuit may shed a light to understand the strange behavior behind chaos in order to make much efficient synchronized circuits in the future.

\section{CONCLUSIONS (SONUÇLAR)}

A new sweep up/down phenomenon, which has been encountered in a recently developed R2L2D circuit with double inductors and diodes has been noticed. The proposed circuit indicates a wider chaotic region compared to the traditional RLD circuit. While chaotic region is observed till $V=7.17 V$ in the sweep up case, it appears at lower values than $V=6.88 \mathrm{~V}$ in the sweep down case. Thus a certain region (i.e. co-existence region) with $\Delta V=0.29 V$ wide skips between threshold of regular and chaotic regimes. This situation proves that the direction of the voltage adjustment is vital in order to determine the dynamics inside the coexistence region. This sweep up/down effect can be important issue for the synchronization and cryptography studies, where the parametric adjustment is utilized frequently.

\section{REFERENCES (KAYNAKLAR)}

1. Kurt, E., Canturk, M. "Bifurcations and hyperchaos from a dc driven non-identical Josephson junction system", Int. J. Bif. Chaos 20(11): 3725-3740, (2010).

2. Kurt, E., Canturk, M. "Chaotic dynamics of resistively coupled DC-driven distinct Josephson junctions and the effects of circuit parameters", Physica D: Nonl. Phen. 238(22): 2229-2237, (2009).

3. Kurt, E. "Nonlinearities a non-autonomous chaotic circuit with a non-autonomous model of Chuas diode", Phys. Scr. 74: 22-27, (2006).

4. Kurt, E., Ozturk, M.K., Kasap, R. "Investigating the most appropriate parameters of the non-linear resistor circuit time series", J. Inst. Sci.\& Tech. Gazi Uni. 14(4): 12611269, (2001).

5. Thompson, J.M.T., Bishop, S.R. Nonlinearity and Chaos in Engineering Dynamics, ( John Wiley and Sons, UK), (1994).

6. Kennedy, M.P., Rovatti, R. Setti, G. (edited by Raton, B.) Chaotic Electronics in Telecommunications, (CRC Press, USA), (2000).

7. Uchida, A., Davis, P., Itaya, S. "Generation of information theoretic secure keys using a chaotic semiconductor laser", Appl. Phys. Lett. 83(15): 3213 3215, (2003).

8. Van Wiggeren, G.D., Roy, R. "Communication with chaotic lasers", Science 279, pp. 1198, (1998).

9. Kapitaniak, T. Controlling Chaos, (Academic Press, USA), (1996).

10. Stojanovski, T., Pihl, J., Kocarev, L. [2001] "Chaos based random number generators Part II: Practical realization", 
IEEE Trans. Circuits Systems I: Fund. Theory and Appl. 48: 382-385, (2001).

11. Tsubone, T., Saito, T. [1998] "Hyperchaos from a 4-D manifold piecewise-linear system", IEEE Trans. Circuits Systems I: Fund. Theory and Appl. 45: 889894, (1998).

12. Linsay, P. S. [1981] "Period doubling and chaotic behaviour in a driven anharmonic oscillator", Phys. Rev. Lett. 47: 1349-1352, (1981).

13. Kurt, E., Ciylan, B., Taskan, O.O., Kurt, H.H "Bifurcation analysis of a resistor-double inductor and double diode circuit and a comparison with a resistorinductor-diode circuit in phase space and parametrical responses", Scientia Iranica 21(3): 935-944, (2014).

14. Testa, J., Perez, J., Jeffries, C. "Evidence for universal chaotic behaviour of a driven oscillator", Phys. Rev. Lett. 48: 714-717, (1982).

15. Itoh, M., Chua, L.O. "Dynamics of memristor circuits", Int. J. Bif. Chaos 24(5): 1430015, (2014).

16. Azzouz, A., Duhr, R., Hasler, M. "Transition to chaos in a simple nonlinear circuit driven by a sinusoidal voltage source", IEEE Trans. Circuits Systems 30(12): 913-914, (1983).
17. Su, Z., Rollings, R.W., Hunt, E.R. "Universal properties at the onset of chaos in diode resonator systems", Phys. Rev. A 40(5): 2689-2697, (1989).

18. van Buskirk, R, Jeffries, C. "Observation of chaotic dynamics of coupled nonlinear oscillators", Phys. Rev. A 31: 3332-3357, (1985).

19. Huang, J.Y. \& Kim, J.J. "Type-II intermittency in a coupled nonlinear oscillator: Experimental observation", Phys. Rev. A 36(3): 1495-1497, (1987)

20. Kim, Y.H., Kim, J.J. "Observation of quasiperiodicity in a single diode circuit", J. Korean Phys. Soc. 27(2): 225 227, (1994).

21. Kasap, R., Kurt, E. "Investigation of chaos in the RLdiode circuit by using the BDS test", J.Appl. Math. Decision Sci. 2(2): 193-199, (1998).

22. Kurt, E., Acar, S., Kasap, R. "A comparison of chaotic circuits from a statistical approach", Math. Comp. App. J. 5(2): 95-103, (2000).

23. Inaba, N., Nishio, Y., Endo "Chaos via torus breakdown from a four-dimensional autonomous oscillator with two diodes", Physica D 240(11): 903-912, (2011).

24. Manimehan, I., Philominathan, P. "Composite dynamical behaviors in a simple seriesparallel LC circuit", Chaos, Solit. Fractals 45(12): 1501-1509, (2012). 